UNNES RAINBOW Vol. 8(1)(2019)

\title{
Techniques of Translating Adele's 25 Album Into Indonesian and The Naturalness Quality
}

\author{
Edi Hartono ${ }^{\bowtie}$, Issy Yuliasri
}

English Department, Languages and Arts Faculty, Universitas Negeri Semarang, Indonesia

\begin{abstract}
Article Info
Article History:

Received 4 April 2019

Approved 25 July 2019

Published 29 July 2019

Keywords:

translation techniques,

naturalness, song, lyric.

Abstract

This research focuses on analyzing the use of translation techniques and the naturalness of the translated lyrics. The objectives of the study were to investigate the translation techniques used to translate song lyrics and to identify the naturalness in translated lyrics of Adele's 25 album songs. This research was done qualitatively. This research applied the translation technique classification proposed by Molina and Albir (2002:509-511) and the naturalness assessment proposed by Nababan (2012). Data analysis was done by comparing the original language and the translated lyrics version to find out the most used of translation techniques. The rater survey was also done by asking 20 respondents to find out the naturalness level of the translated lyrics. The results of the study showed that there were 276 data of the translated lyrics and 11 translation techniques found in this research. Literal translation technique was the most frequent used, followed by Linguistic compression. Some other translation techniques were used moderately such as, Established equivalent, reduction, and discursive creation. The rest techniques were used in low frequency such as modulation, amplification, compensation, linguistic amplification, transposition, and particularization. In terms of naturalness assessed by twenty respondents found that around $61.95 \%$ of the data were considered natural translation, $28.80 \%$ were less natural and $9.23 \%$ were unnatural. The translation techniques with the highest naturalness were Linguistic amplification technique with a percentage $68.18 \%$, particularization was contributing most to less natural translation with percentage $45 \%$, and the transposition technique was contributing most to unnatural translation with percentage $23 \%$. From the data, it can be concluded that the translated lyrics of Adele's 25 album were mostly natural.
\end{abstract}




\section{INTRODUCTION}

Language is one of the important aspects in life, it's an important function in around the world as the tool of communication in order to understand and to get the meaning in communication, human need languages in their daily lives. However, the vast number of languages makes people difficult to understand one and another language. Nowadays, the diversity of language leads people to be able to communicate in different languages, In this case, translation is very necessary to help people in understanding the foreign language. Fedora (2015) stated that translation is necessary in the era of information and communication today, and it is also done to literary works, such as a novel, short story, and poetry, However, a translation will be a bridge to overcome those difficulties. In addition, (Nida 1969: 12) also stated that "Translating consists in reproducing in the receptor language the closest natural equivalent of the source language message, first in terms of meaning and secondly in terms of style". Catford (1965: 20) also points out that, "Translation is the replacement of textual material in one language by equivalent textual material in another language. In this definition, the most important thing is the equivalent textual material; nonetheless, it is unclear in terms of the type of equivalence.

In this digital era, there are some music applications such as Smule, JOOX, iTunes, and Spotify. The fact is, most of the Indonesian people more often listening to the western song instead of the original song of Indonesia, it can be seen as there is always a western song in the top 10 of chart music on those applications. The phenomena also showed that currently most of people prefer to sing or perform western's songs. We can see those phenomena in social media (such as YouTube and Instagram), in some events such as wedding ceremony, and in a talent show program. However, the point of the problem is sometimes people just sing the song and didn't know the meaning of its song.

In order to know the meaning of the lyric, People nowadays can access it easily by searching it on the websites. Most of the media recently provide the lyric song including its translation. However, even we can access the translated lyrics, we don't know either the translated lyric was natural or not, it is because a different language has different cultures. These problems certainly lead people to miss understand about the meaning. So, it is important to translate a language as natural as possible in order to help people understanding the meaning. Larson (1198) said that a translation is basically a change of form. In translating a text, a translator must be careful because she/he has to translate the text accurately, naturally, and communicatively in order to make the readers easier to understand the text.

Assessing the Naturalness of a translated product is very important because it will show whether the translation delivers the information or the message of the source language or not. Barnavel in his book "introduction to semantic and translation" (1980) says, for a translation to be acceptable is to use a natural form of the target text. Moreover, Nida and Taber (1969) consider translation a good one when it doesn't show to be a translation. In addition, There are several criteria of good translation based on experts such as Larson (1998), Barnwell (1980, p. 115) and Nababan (2003, p. 86), from their explanations, it can be concluded that there are three most important qualities of a good translation, such as accuracy, clarity, and naturalness. It is showed that naturalness is one of the important thing that must be considered by the translator. It is because if the translator already translates the source language SL accurately and clearly but the sentence of the TL sounds awkward and unnatural, it will make the reader difficult to understand the information of the text. In this case, the translator should be able to choose the appropriate word which has the closest meaning to reach a natural translation.

Translating song lyrics is not an easy thing since it is focused on the meaning and about how to deliver the message. When translating song lyrics, the translator should be using some translation techniques to reach a proper translation as the resulted. According to Molina 
and Albir (2002: 510-511), there are 18 kinds of translation techniques, namely: 1) Adaptation, 2) Amplification, 3) Borrowing, 4) Calque, 5) Compensation, 6) Description, 7) Discursive Creation, 8) Established Equivalent, 9) Generalization, 10) Linguistic Amplification, 11) Linguistic Compression, 12) Literal Translation, 13) Modulation, 14) Particularization, 15) Reduction, 16) Substitution, 17) Transposition, and 18) Variation.

Relate to translation techniques, Yuliasri and Hartono (2014) were conducted research entitled Translation Techniques and Equivalence in the Indonesian Translation of Humor in Harry Potter and the Sorcerer's Stone. The research found out that in translating in humor, the translator has used 14 translation techniques with literal translation as the most dominant one. They also reveal that the use of the generalization technique has caused the most reduced humor. Findings of the most reader's response analysis also suggest that the humor contained in the novel is somewhat reduced/lost in its translation.

Adele Laurie Blue Adkins is a British singer-songwriter who has sold millions of albums worldwide and won a total of 15 Grammys as well as an Oscar. 25 Album was No. 1 on iTunes in 110 countries. In the U.S. Album 25 sold 3.38 million copies in seven days. Recited from www.imdb.com (accessed on October 23, 2018). In this research, the researcher used 11 songs from this album. Those are Hello, send my love, I miss you, when we were young, remedy, water under the bridge, river Lea, love in the dark, Million years ago, all I ask, and Sweetest Devotion.

The objectives of the study were to investigate the translation techniques used to translate and to identify the naturalness in translated lyrics of Adele's 25 album.

\section{METHODS}

The research method used in this research was Descriptive Qualitative Research. In this research, the researcher used both the original lyrics and translated lyrics of Adele's 25 album. The research started from analyzing the translation techniques used in translating lyrics of Adele's 25 album. The translation technique analysis was conducted by using translation techniques proposed by Molina and Albir (2002). There are adaptation, amplification, borrowing, calque, compensation, description, discursive creation, established equivalent, generalization, literal translation, modulation, particularization, reduction, substitution, transposition, and variation.

To assess the Naturalness of translated lyric, the researcher gave a questionnaire to twenty respondents who are students of the English Department of Universitas Negeri Semarang. The questionnaires were given to analyze whether the translated lyrics of Adele's 25 album were translated naturally or not. The naturalness assessment used by the researcher is proposed by Nababan (2012). There is a classification score of the naturalness rating instrument. It's given Score 3 when Translation feels natural, use the common term for the target reader, and use the word, phrase, clause, and sentence which is appropriate with the rule of Bahasa Indonesia. It's given Score 2 when translation feels natural, but there is little bit problem in some terms; a few grammatical errors. It's given Score 1 when Translation is unnatural, use an unusual term and unappropriated rule of Bahasa Indonesia.

\section{RESULTS AND DISCUSSIONS}

\section{Translation Technique}

In this research, out of 18 translation techniques proposed by Molina and Albir, there were only 11 techniques used by the translator to translate 11 song lyrics of Adele's 25 album. In this research, there are 276 valid data (lyrics) found in the translated lyrics of Adele's 25 album. Literal Translation technique is the most frequent technique found in the translated lyric. The other techniques are as follows: (2) linguistic compression. (3) Established Equivalent technique. (4) Reduction technique. (5) Discursive creation technique. (6) Modulation technique. (7) Amplification technique. (8) Compensation technique. (9) Linguistic 
amplification. (10) Transposition technique. (11) Particularization Technique.

The following are the detailed descriptions of each translation technique found in the translated lyrics of Adele's 25 album. The detailed description is also provided with some examples.

\section{Literal Translation}

Literal translation is a technique that translates a word or expression in word for word. The original lyric is translated literally without any addition or reduction into translated lyrics. Most of the techniques found in the translated lyrics were using Literal translation. The example can be seen below:

(1)

OL: I want your heaven and your ocean

TL: $\quad$ Aku ingin surgamu dan lautanmu juga

BT: I want your heaven and your oceans too

The data above showed that the translator used literal technique in translating the lyrics. The original lyric "I want your heaven and your oceans too" that was translated into "Aku ingin surgamu dan lautanmu juga (I want your heaven and your oceans too)". In this case, the translator seemed to translate the original lyric in word by word. The translator translated it without adding anything to the meaning or taking anything away. It originally reproduces the meaning and intent of the original. The original lyric has the same meaning and also hasn't made any changes such as changing grammatical or changing in the structural part.

\section{Linguistic Compression}

Linguistic compression is a translation technique to concentrate linguistic elements in the target text (TT). The example can be seen below:

\section{OL: To tell you I'm sorry \\ TL: Tuk meminta maaf \\ BT: $\quad$ to apologize}

The lyric above were translated by using linguistic compression technique. The original lyric "To tell you I'm sorry" was translated into
"Tuk meminta maaf". Literally, "To tell you I'm sorry" means "untuk mengatakan padamu maafkan $a k u$ ". However, in the translated lyric, the translator concentrates the original lyric into "Tuk meminta maaf" which means "to apologize". As the result, the translator compressed in the original lyric "To tell you I'm sorry" only become "Tuk meminta maaf (to apologize)". Although the original lyric has been translated used linguistic compression technique it still has an equivalent meaning and message.

\section{Established Equivalent}

Established equivalent is a technique that uses term or expression to describe the same situation by different stylistic or structural. The example can be seen below:

OL: Your love, it is my truth

TL: Cintamu, itulah keyakinanku

BT: Your love, that's my faith

The translator used established equivalent technique to translate the lyric in order to refer the case where language describes the same situation by different stylistic. In this data, instead of translated into "kebenaran", the words "my truth" was translated into "keyakinanku". Although those two words are different, it has the same message. Indonesian commonly used the word "faith" instead of "truth" to express how people believe in something, but in this data, the translator used a different expression to fit the meaning. At the end, the original lyric "Your love, it is my truth" was translated into "Cintamu, itulah keyakinanku".

\section{Reduction}

Reduction technique is employed to suppress a source language information item in the target language. It is in opposition to Amplification technique. The example can be seen below:

(4)
OL: $\quad$ Your body standing over me
TL: Tubuhmu di atasku
BT: $\quad$ Your body is above me 
The original lyric "Your body standing over me" was translated into "Tubuhmu di atasku" The translator has used reduction technique as there's a reduction in translating the lyrics. The original lyric "Your body standing over me" literally means "tubuhmu berdiri di atasku", but the translator reduces or eliminates the word "standing". As the result, the original lyric "Your body standing over me" was translated into "Tubuhmu di atasku" instead of "tubuhmu berdiri di atasku". The translator seems to reduce the translated lyrics to make the content simpler and focus on the purpose of the text. Even the word was omitted from the sentences, those do not change the meaning.

\section{Discursive creation}

Discursive Creation technique is employed to establish a temporary equivalence that is totally unpredictable and out of context. It usually happens in translating the title of songs, movies, television shows, books, stories, and other literary works. The example can be seen below:

(5)

OL: You never seem to make it through the door

TL: Kau terlihat tak pernah jadikan itu kesempatan

BT: You never seem make it a chance

The original lyric "You never seem to make it through the door" was translated was translated into "Kau terlihat tak pernah jadikan itu kesempatan". Instead of translating the words "through the door" into "melalui pintu", the translator established an unpredictable equivalence and translated it into "kesempatan" which means "a chance" in English. Probably, the translator wants to explain the purpose of the lyric more explicitly by creating an unpredictable meaning. as the result, the translator translated the lyric "You never seem to make it through the door" into "Kau terlihat tak pernah jadikan itu kesempatan (You never seem make it a chance).

\section{Modulation}

Modulation is a technique that changes the point of view in the Target Text (TT) in order to focus or cognitive category in relation to Source Text (ST). Several of the text can be seen in the example bellow:

(6)

OL: When the night keeps you from sleeping

TL: Saat malam kau tak tertidur

BT: when at night you don't fall asleep

The translator used modulation technique in translating the lyric. The original lyric "When the night keeps you from sleeping" which means "saat malam membuatmu tidak tidur", was translated into "Saat malam kau tak tertidur (when at night you don't fall asleep)". In this case, the translator changed the point of view of "keeps you from sleeping (membuatmu tidak tidur)" into "kau tak tertidur (you don't fall asleep)" in order to make the purpose understandable. However, although the translator changed the point of view, the translated lyric still has the same message or meaning towards the original lyric since "(When the night keeps you from sleeping) saat malam membuatmu tidak tidur" has relevance meaning or message toward "Saat malam kau tak tertidur" in the Translated Lyric.

\section{Amplification}

Amplification technique is applied to introduce details that are not formulated in the source language. Information, explicating paraphrasing, and footnotes are types of this technique. It is in opposition to Reduction technique. The example can be seen below:

(7)

OL: And your heart makes you feel like a fool

TL: Dan hatimu membuatmu merasa seperti orang bodoh

BT: And your heart makes you feel like a fool man

The data above showed that the translator translated the lyric used amplification technique. It can be seen in the original lyric "And your heart makes you feel like a fool" that was translated into "Dan hatimu membuatmu merasa seperti orang bodoh". In this data, the translator adds detail 
information to the translated lyrics. In this case, instead of translating "fool" into "bodoh", the translator added additional information "orang" as a Noun to the translated lyrics to assist in delivering the message to the readers and to give detail information about to whom the words "fool" was intended. As the result, the translator translated the original lyric "And your heart makes you feel like a fool" into "Dan hatimu membuatmu merasa seperti orang bodoh.

\section{Compensation}

Compensation technique is employed to introduce an Original Lyric element of information or stylistic effect in another place in the Translated Lyric because it cannot be reflected in the same place in the Original Lyric. The example can be seen below:

\section{(8)}

OL: That I never meant to hurt you or lie straight to your face

TL: Kalau aku tak pernah bermaksud untuk menyakitimu atau berbohong di hadapanmu

BT: that I never meant to hurt you or lie in front of you

The translator translated the original lyric "That I never meant to hurt you or lie straight to your face" into "Kalau aku tak pernah bermaksud untuk menyakitimu atau berbohong di hadapanmu". In this case, the translator translated the sentence in this lyric "straight to your face" into "tepat di wajahmu". The translator replaced the item information and translated it into "di hadapanmu" which means "in front of you" in English. The translator used compensation technique because the element of information in the original lyric cannot be realized in the same section in the translated lyric or it will lose the meaning if the translator translated the lyric literally.

\section{Linguistic Amplification}

Linguistic Amplification technique is used to add linguistic elements. In addition, this technique is often used in consecutive interpreting and dubbing. It is in opposition to Linguistic Compression technique. The example can be seen below:
(9)

OL: $\quad$ Stop asking me to stay

TL: Berhentilah memintaku tuk tetap tinggal

BT: $\quad$ stop asking me to keep stay

In the data above, the sentence "Stop asking me to stay" was translated into "Berhentilah memintaku tuk tetap tinggal (stop asking me to keep stay)." If the original lyric "Stop asking me to stay" was translated literally, the translated lyric should be "berhenti memintaku untuk tinggal". Here the translator seemed using linguistic amplification technique since the linguistic element "Tetap (keep)" was added into the translated lyrics. The linguistic element "keep" was added in order to emphasize the meaning contained in the lyrics. As the result, the translator translated the original lyric "Stop asking me to stay" into "Berhentilah memintaku tuk tetap tinggal (Stop asking me to keep stay)", instead of "berhenti memintaku untuk tinggal "Stop asking me to stay)". So, it was called linguistic amplification technique.

\section{Transposition}

Transposition is a technique that changes a grammatical category in relation to the source text. Transposition can be changing singular to plural, a position of adjective, and also changing the word class. In the transposition technique there found 6 . Several of the text can be shown in the example below:

\section{OL: Let me photograph you in this light}

TL: Biarkan aku memotretmu dalam cahaya ini

BT: Let me take a picture of you in this light

The translator seemed translated the original lyric by employing transposition technique. In this data, the original lyric "Let me photograph you in this light" was translated into "Biarkan aku memotretmu dalam cahaya ini (Let me take a picture of you in this light)". In this case, Transposition technique used by the translator by changing the word class from a noun into a verb. The word "photograph" in the original lyric literally means "Gambar (photo)" which classified as a noun. Yet, in this data, the translator 
changed it into "memotret" in Bahasa which classified as a verb. So, from the data above it is showed that the translator used Transposition technique to translate the lyrics.

\section{Particularization}

Particularization technique is employed to use a more precise or concrete term. It is in opposition to Generalization technique. The example can be seen below:

(11)

OL: Come whenever I'll be the shelter that won't let the rain come through

TL: $\quad$ Datang kapan saja aku akan menjadi rumah yang tak akan membiarkan hujan membasahimu

BT: Come anytime I will be a house that won't let rain wet you

The data above showed that the translator used Particularization technique to translate the original lyric. In the data, the original lyric "Come whenever I'll be the shelter that won't let the rain come through" was translated into "Datang kapan saja aku akan menjadi rumah yang tak akan membiarkan hujan membasahimu". The translator creates the translated lyric more specific, concrete, and precise than the original lyric. The words "shelter". If it is translated literally, "shelter" should mean "tempat berlindung or gubuk". However, the translator decided to use the word "rumah" to make it more specific and more concrete.

\section{The Naturalness of Translation}

A questionnaire of naturalness rating was given to 20 respondents. They were assessing the questionnaire whether the translation was Natural, less natural, or unnatural. The result is presented in the table below.

Table Naturalness Assessment Score

\begin{tabular}{lccc}
\hline Definition & Score & Total & \% \\
\hline Natural & 3 & 3420 & $62 \%$ \\
Less natural & 2 & 1590 & $28.8 \%$ \\
Unnatural & 1 & 510 & $9.2 \%$ \\
\hline
\end{tabular}

The translated lyrics of Adele's 25 album which got a score of 3 were $62 \%$. while the translations that got the score of 2 were $28.8 \%$, followed by the unnatural that got $9.2 \%$. In general, the translated lyrics of Adele's 25 album were natural due to the high level of natural translation

\section{Relation of Translation Techniques and Naturalness}

This research also showed the relation between translation techniques and the naturalness of the translated lyrics of Adele's 25 album. Linguistic amplification technique was got the highest naturalness level with a percentage $68.18 \%$, followed by Modulation (67.91\%), Linguistic compression (67.56), Reduction (67.50), Establish equivalent (65.80), Amplification (65\%) and literal translation (60.32). There were two techniques which got the level of naturalness under $60 \%$, those techniques were discursive creation (59.41), compensation (56.81\%). The last was two techniques which got very low naturalness level in the range of $30 \%$, those techniques were particularization (36\%) and transposition (33\%).

\section{CONCLUSION}

Answering the first research question, this research found that out of 18 translation techniques proposed by Molina and Albir only 11 techniques were used by the translator to translate 11 Adele's song lyrics of album 25. Literal translation technique was the most frequent translation technique used, followed by Linguistic compression. Some other translation techniques were used moderately such as, Established equivalent, reduction, and discursive creation. The rest techniques were used in low frequency such as modulation, amplification, compensation, linguistic amplification, transposition, and particularization.

In terms of Naturalness assessed by 20 respondents, around $61.95 \%$ of the data were considered natural translation, while $28.80 \%$ were less natural and $9.23 \%$ were unnatural. The translation techniques that contribute most to 
natural translation were Linguistic amplification technique, while particularization was contributed most to less natural. The last was transposition technique that contributes most to unnatural translation. From the data above, it showed the naturalness rating of the translated lyrics was quite high. It can be concluded that the majority of the translated lyrics of Adele's 25 album were rated natural.

\section{SUGGESTIONS}

This research mainly focused on analyzing translation techniques and the naturalness in translating song lyrics of Adele's 25 album. Based on the research result, there're some data which are still less natural. It's because the translator still maintains some foreign words and proverbs and didn't change it properly to the target language. The translator also didn't use proper words that are appropriate with Bahasa Indonesia rules, so it makes the translation less natural for the raters. For the translator, it will be better if the translator translates those using common words in the target language and use the words which are appropriate with Bahasa Indonesia rules. If the translator was difficult to find the equivalent translation in the target language, it is better for the translator to focus on the meaning. For other researchers, based on the finding, I suggest to examine the effect of the translation techniques on other aspects of translation quality such as readability, accuracy or singability dealing with song lyrics to develop translation studies.

\section{REFERENCES}

Albir, L. M. (2002). Translation Techniques Revisited: A Dynamic and Functionalist Approach. Meta, XLVII, 498-512.

Adele's 25 album. (2018, November 2). Retrieved from https://www.imdb.com

Creswell, J. W. (2003). Research Design: Quantitative, Qualitative, and Mixed Method. United States of America: Sage Publications.

Education, F. O. F. (2015). Quality Assessment of the " Thousand Years " Song Lyrics in Translation mid Exam Result of 6 th Semester Students of English Education of STKIP Ponorogo.
Fadaee, E. (2011). Translation naturalness in literary works: English to Persian, 2(December), 200205. https://doi.org/10.5897/IJEL11.089

Fresco, P. R. (2009). Naturalness in the Spanish Dubbing Language: a Case of Not-so-close Friends. Meta: Journal Des Traducteurs, 54(1), 49. https://doi.org/10.7202/029793ar

Hartono, Rudi. 2017. Teori Penerjemahan (A Handbook For Translators). Semarang: Cipta Prima Nusantara.

Mangatur Nababan, A. N. (2012). Pengembangan Model Penilaian Kualitas Terjemahan. Artikel Kajian Linguistik dan Sastra, 24, 39-57.

Mujiyanto, Y. (2011). Petunjuk Penulisan Skripsi. Semarang: UNNES Press.

Prasetyo, A. J. I. (2017). Naturalness Of Indonesian Translated Similes In Doyle' S Short Stories. FACULTY OF LANGUAGES AND ARTS.

Rogers, M. (1999). Naturalness and Translation. SYNAPS. Fagsprak, Kommunikasjon, Kulturkunnskap, 2(99), 9-31.

Techniques, T., By, U., In, S., \& English, T. (2014). Translation Techniques Used By Students in Translating English News Items, 4(2), 90-98.

Yuliasri, I. (2016). Translation Techniques and Pragmatic Equivalence in Indonesian Translation of Humorous Utterances in the Walt Disney's Donald Duck Comics. Prosiding Prasasti, O(0), 409-414. https://doi.org/10.20961/PRAS.V0I0.1554.G $\underline{1444 .}$. 